medRxiv preprint doi: https://doi.org/10.1101/2021.03.23.21254214; this version posted March 26, 2021. The copyright holder for this preprint (which was not certified by peer review) is the author/funder, who has granted medRxiv a license to display the preprint in perpetuity.

It is made available under a CC-BY 4.0 International license .

\title{
Mouth-rinses and SARS-CoV-2 viral load in saliva: A living systematic review
}

Running title: Mouth-rinses and SARS-CoV-2 viral load in saliva

Keywords: Systematic Review; Mouthwashes; SARS-CoV-2; Viral Load, Saliva.

Akram Hernández-Vásquez (Corresponding author)

Universidad San Ignacio de Loyola, Vicerrectorado de Investigación, Centro de Excelencia en Investigaciones Económicas y Sociales en Salud, Lima, Peru

Email: ahernandez@usil.edu.pe

ORCID: 0000-0003-1431-2526

Antonio Barrenechea-Pulache

Universidad Científica del Sur. Lima, Peru

Email: abarrenecha@cientifica.edu.pe

ORCID: 0000-0003-4583-5434

Daniel Comandé

Instituto de Efectividad Clínica y Sanitaria (IECS). Buenos Aires, Argentina

Email: dcomande@iecs.org.ar

ORCID: 0000-0002-7111-5169

Diego Azañedo

Independent Researcher. Lima, Peru

Email: diego.azanedo@gmail.com

ORCID: 0000-0003-1375-8788

Author contributions: AHV and DA conceived the study. All authors contributed to the design of the study. DA and AHV were involved in planning, supervised, and validated the work. DC executed the searches and de-duplicated the references. For the review, AHV and ABP contributed to the data screening, data extraction, and assessment of study quality. AHV, ABP, and DA contributed to the analysis of the results and to the writing of the manuscript. All authors contributed to the preparation of tables and figures. All authors read and approved the final manuscript.

Sources of Finance: None.

Conflicts of Interest: The authors declared that they had no conflicts of interest.

\section{Correspondence:}

Akram Abdul Hernández Vásquez

Address: Universidad San Ignacio de Loyola, 550 La Fontana Av., La Molina 00012, Lima, Peru. Phone: (+511) 371-1000

Email: ahernandez@usil.edu.pe 
medRxiv preprint doi: https://doi.org/10.1101/2021.03.23.21254214; this version posted March 26, 2021. The copyright holder for this preprint (which was not certified by peer review) is the author/funder, who has granted medRxiv a license to display the preprint in perpetuity.

It is made available under a CC-BY 4.0 International license.

\begin{abstract}
Objective. To conduct a living systematic review of the clinical evidence regarding the effect of different mouth-rinses on the viral load of SARS-CoV-2 in the saliva of infected patients. The viral load in aerosols, the duration of the reduction in viral load, viral clearance, SARS-CoV-2 cellular infectivity, and salivary cytokine profiles were also evaluated.
\end{abstract}

Materials and methods. This study was reported using the PRISMA guidelines. An electronic search was conducted in seven databases and in preprint repositories. We included human clinical trials that evaluated the effect of mouth-rinses with antiseptic substances on the viral load of SARS-CoV-2 in the saliva of children or adults that tested positive for SARS-CoV-2 using reverse transcriptase polymerase chain reaction (RT-PCR). Risk of bias was assessed using the ROBINS-I tool. PROSPERO registration number CRD42021240561.

Results. Four studies matching eligibility criteria were selected for evaluation ( $n=32$ participants). Study participants underwent oral rinses with hydrogen peroxide $(\mathrm{H} 2 \mathrm{O} 2)$ at $1 \%$, povidone-iodine $(\mathrm{PI})$ at $0.5 \%$ or $1 \%$, chlorhexidine gluconate $(\mathrm{CHX})$ at $0.2 \%$ or $0.12 \%$ or cetylpyridinium chloride $(\mathrm{CPC})$ at $0.075 \%$. Only one study included a control group with sterile water. Three of the studies identified a significant reduction in viral load up to 3,4 , and 6 hours after the use of mouthwashes with PI, CHX, and CPC or PI vs. sterile water, respectively, while one study did not identify a significant reduction in viral load after the use of $\mathrm{H} 2 \mathrm{O} 2$ rinses.

Conclusions. According to the present systematic review, the effect of the use of mouth-rinses on SARSCoV-2 viral load in the saliva of COVID-19 patients remains uncertain. This is mainly due to the limited number of patients included and a high risk of bias present in the studies analyzed. Evidence from welldesigned randomized clinical trials is required for further and more objective evaluation of this effect. 
medRxiv preprint doi: https://doi.org/10.1101/2021.03.23.21254214; this version posted March 26, 2021. The copyright holder for this preprint (which was not certified by peer review) is the author/funder, who has granted medRxiv a license to display the preprint in perpetuity.

It is made available under a CC-BY 4.0 International license.

\section{INTRODUCTION}

The SARS-CoV-2 pandemic has had a great impact on the health of the global population due to its increasing spread and lack of treatment to prevent infection or reduce disease severity. Since the first case report in November 2019 (Kpozehouen et al. 2020) and up to March 2021, more than 121 million infections and over 2.6 million deaths have been registered and cases continue to increase (Dong, Du, Gardner 2020). The global scientific community has therefore started a series of studies aimed at identifying public health measures and technologies to mitigate the spread of this disease.

So far, the only effective measures endorsed by the World Health Organization (WHO) to control and prevent the transmission of this disease at the community level are continuous hand washing, physical distancing, and the correct use of face masks (World Health Organization 2021). Likewise, in relation to hospital care, the WHO has recommended the use of personal protective equipment (glasses / face shields, gloves, gowns, and N95 respirators or their equivalents), for health personnel who care for patients with COVID-19 and perform activities with a high risk of contagion, such as aerosol-generating procedures performed by dentists. These procedures can cause viral shedding through aerosols and splashes generated during dental care, potentially infecting health care personnel or patients seen between appointments.

Since there is no known treatment for COVID-19, the administration of a series of drugs currently being tested in clinical trials or approved for other uses has been proposed for off-label use during the pandemic, as preventive or recuperative therapies for COVID-19 based on studies describing some level of in vitro activity against SARS-CoV-2. Nonetheless, clinical studies published later have shown a lack of efficacy of these drugs to prevent or treat the disease, and in some cases, they were associated with higher mortality and morbidity (Ghazy et al. 2020). In the field of dentistry, various investigators have proposed that the preprocedural use of mouth-rinses that include antiseptic substances could generate a reduction of SARSCoV-2 viral load in the saliva of infected patients (O'Donnell et al. 2020; Peng et al. 2020). These proposals are mainly based on evidence from in vitro studies (Meister et al. 2020), and more recently, human clinical trials (Seneviratne et al. 2020).

In response, international organizations such as the Centers for Disease Control and Prevention and the American Dental Association (American Dental Association 2020; Center for Disease Control and Prevention 2020) have incorporated recommendations about the use of mouth-rinses before dental procedures in their guidelines for dental health care during the COVID-19 pandemic. These recommendations are aimed at reducing the load of oral microorganisms in aerosols generated during treatment, emphasizing the lack of clinical evidence about their efficacy in reducing the transmission of SARS-CoV-2. This has generated controversy among the population, mouth-rinse manufacturing companies, and health care professionals and researchers with regard to the applicability of this measure in the prevention against SARS-CoV-2 infection (Reis et al. 2021).

Due to the current interest in the utility of this oral hygiene product in the prevention of SARS-CoV-2 infection, the objective of this study was to make a living systematic review of the clinical evidence regarding the effect of different mouth-rinses on the viral load of SARS-CoV-2 in the saliva of infected patients. Additionally, we aimed to evaluate the effect of mouthwashes on the quantification of the virus in the aerosols generated during dental care of infected patients, and the duration of the reduction of viral load in saliva and aerosols. We will also perform periodic updates of the study search, since according to the ClinicalTrials.gov registry, clinical trials on the subject are ongoing (Alzahrani 2021; Jacox 2021; Villar 2021), and will eventually provide new clinical evidence to complement the currently published information and the conclusions of this systematic review. 
medRxiv preprint doi: https://doi.org/10.1101/2021.03.23.21254214; this version posted March 26, 2021. The copyright holder for this preprint (which was not certified by peer review) is the author/funder, who has granted medRxiv a license to display the preprint in perpetuity.

It is made available under a CC-BY 4.0 International license.

\section{MATERIALS AND METHODS}

The protocol of this living systematic review was prospectively registered in accordance with the Preferred Reporting Items for Systematic Reviews and Meta-Analyses Protocols (PRISMA-P) statement (Moher et al. 2015) on PROSPERO with reference number CRD42021240561. We will update the search on a monthly basis according to the availability of new evidence as a living systematic review (Elliott et al. 2017) and we plan to maintain the review in a living mode for at least 12 months from the publication of the protocol. This article currently reports the basal findings from relevant articles identified up to February 26th, 2021. The reporting of the results complies with the 'Preferred Reporting Items for Systematic reviews and Meta-Analyses' (PRISMA) guidelines (Moher 2009) (Appendix Checklist 1).

\section{Inclusion Criteria}

We included human clinical trials that evaluated the effect of mouth-rinses with antiseptic substances on the viral load of SARS-CoV-2 in the saliva of patients, children, or adults with COVID-19, diagnosed using reverse transcriptase polymerase chain reaction (RT-PCR). Likewise, we included studies that evaluated the outcome of viral load on aerosols generated during dental procedures, the duration of the reduction in viral load, viral clearance, SARS-CoV-2 cellular infectivity in saliva, and salivary cytokine profiles. We did not restrict our criteria to any dosage, duration, or timing of mouth-rinses. The comparison of interest was distilled water, sterile water, tap water, saline solution, or no treatment. We included articles published in both peer-reviewed journals and preprints and only publications written in English or Spanish. We excluded comments, conference abstracts, interviews, and studies developed in animal models or in vitro conditions. The preprints included will be reassessed at the time of peer-reviewed publication, and the most current version will be included.

\section{Search strategy}

A systematic electronic search of articles published until February 26th, 2021 was conducted using PubMed, CINAHL, The Cochrane Library, Embase, Scopus, Dentistry \& Oral Sciences Source, and LILACS databases. Preprint repositories including medRxiv and bioRxiv were also searched.

A librarian (DC) developed the search strategies which were later validated by the other authors (AHV, ABP and DA). We initially designed a search strategy in PubMed which was adapted to the other databases containing the following terms with synonyms and other medical descriptors: "coronavirus», "SARS-CoV2», and "Mouth-rinse». The details of the search terms used for the search are shown in Appendix Table 1. The same search strategies will be run on every update. We also manually screened the references of the original studies and reviews included to identify additional eligible studies. No date, language, study design, publication status, or language restriction was applied to the searches in the databases.

In this living systematic review, three independent authors (DC, ABP, and AHV) will receive an updated literature search file every month. They will continuously include relevant newly published or unpublished studies as per the above inclusion criteria.

\section{Study selection}

Initially, the results of the electronic search were imported to the reference management software EndNote X9. We eliminated all duplicate registries following the methodology described by Bramer et al. (Bramer et al. 2016). An independent two-stage screening process was undertaken to identify studies meeting the eligibility criteria by two authors (ABP and AHV) using the web application "Rayyan" (Ouzzani et al. 2016). First, we evaluated the registries by title and abstract, and those appearing to meet the inclusion criteria were selected and the remaining were discarded. Afterwards, the full texts of the selected papers were 
medRxiv preprint doi: https://doi.org/10.1101/2021.03.23.21254214; this version posted March 26, 2021. The copyright holder for this preprint (which was not certified by peer review) is the author/funder, who has granted medRxiv a license to display the preprint in perpetuity.

It is made available under a CC-BY 4.0 International license .

evaluated under the same inclusion criteria. Any disagreement was discussed among the reviewers and in case of not being able to make a decision a third reviser took part in the discussion (DA).

\section{Extraction and synthesis of results}

The report of the reduction of viral load of SARS-CoV-2 in saliva or aerosols generated by dental procedures, and the duration of said reduction, was planned, using the different units of measurement registered before and after the use of mouth-rinses according to the report of each study. We also extracted the following information: study design, settings, participant characteristics, study eligibility criteria, intervention, control, and the risk of bias assessment for each study. Data was independently extracted by two authors (ABP and $\mathrm{AHV}$ ) using standardized forms. If these data were not reported, we contacted authors to request them.

The general information about the publications and specific data of each study included was compiled in the summary tables. For any outcome in which data were sufficient to calculate an effect estimate, we planned to conduct a meta-analysis.

\section{Risk of Bias Assessment}

Two authors (AHV and ABP) independently assessed the risk of bias using the ROBINS-I (Risk Of Bias In Non-Randomized Studies of Interventions) tool (Sterne et al. 2016) and disagreements were resolved through discussion with a third author (DA).

\section{Ethical considerations}

We did not solicit the approval of the study by an Institutional Review Board because this is a revision of bibliographic databases.

\section{RESULTS}

The search strategy among the different databases identified 619 articles. After removing duplicates 381 articles were included, and a total of 373 studies were excluded in phase one after review by title and abstract. The remaining eight articles were evaluated in full text, and four were excluded after this evaluation; the reasons for exclusion were: not measuring viral load in saliva or aerosols after the intervention with mouth-rinses (three studies), and only considering qualitative measurements to establish the diagnosis of COVID-19 (one study) (Figure 1). After this process, four studies (Appendix References 1) were included (Gottsauner et al. 2020; Martínez Lamas et al. 2020; Seneviratne et al. 2020; Yoon et al. 2020).

Half of the studies included were original articles (Seneviratne et al. 2020; Yoon et al. 2020), while the rest were short communications (Gottsauner et al. 2020; Martínez Lamas et al. 2020). All were reported in English $(n=4)$. Among the four studies a total of 32 participants were included. The patients subjected to an intervention received mouth-rinses with either hydrogen peroxide $(\mathrm{H} 2 \mathrm{O} 2) 1 \%$, povidone-iodine $(\mathrm{PI})(0.5 \%$ or $1 \%)$, chlorhexidine gluconate $(\mathrm{CHX})(0.2 \%$ or $0.12 \%)$ or cetylpyridinium chloride (CPC) $(0.075 \%)$. Only one study (Seneviratne et al. 2020) included a control group that used sterile water for comparisons. This study included the largest number of participants $(n=16)$ and was also the only study to mention having utilized commercially available mouth-rinses with PI, CHX and CPC (Table 1).

The main objective of these studies was to evaluate the effect of the use of different mouth-rinses on the viral load of SARS-CoV-2 in the oral cavity or saliva. Measurements of this outcome were conducted before and after the intervention at variable time intervals. The minimum interval of time post-intervention for the first measurement was 5 minutes, and the maximum was 6 hours. The highest number of measurements per participant was 5 (basal, after 5 minutes, 1 hour, 2 hours, and 3 hours) and the lowest was 2 (basal and 
medRxiv preprint doi: https://doi.org/10.1101/2021.03.23.21254214; this version posted March 26, 2021. The copyright holder for this preprint (which was not certified by peer review) is the author/funder, who has granted medRxiv a license to display the preprint in perpetuity. It is made available under a CC-BY 4.0 International license.

after 30 minutes). Most studies were carried out in a single day and only one conducted serial measurements at the hospital on days 3 and 6 (Yoon et al. 2020) (Table 1).

The viral load obtained during follow-up was reported as copies $/ \mathrm{mL}$ and only one study reported it as cycle threshold value. Measurements of viral load were highly variable and at times conflicting among the studies (Table 2). Yoon (2020) observed in his intervention on 2 patients during hospital day three, that after use of mouth-rinses based on $\mathrm{CHX}$ the viral load became undetectable during 2 and 4 hours of follow-up, becoming detectable again after 6 hours. Nonetheless, on hospital day 6 the viral load of SARS-CoV-2 was detectable throughout all measurements of follow-up (Yoon et al. 2020). Meanwhile, Seneviratne (2020) identified statistically significant differences in viral load after the use of mouth-rinses in comparisons between CPC vs. water at 5 minutes and 6 hours of follow-up, and PI vs. water at 6 hours of follow-up (Seneviratne et al. 2020). Likewise, Martínez Lamas (2020) observed a progressive reduction of the mean viral load obtained from the four participants from baseline until 3 hours of follow-up (Martínez Lamas et al. 2020). These three authors agree that the use of mouth-rinses could reduce the viral load of SARS-CoV-2 in the saliva samples of patients, reaffirming the need for more thorough studies to confirm these preliminary findings (Martínez Lamas et al. 2020; Seneviratne et al. 2020; Yoon et al. 2020). In contrast, Gottsauner (2020) concluded that mouth-rinses based on $\mathrm{H} 2 \mathrm{O} 21 \%$ did not reduce the intraoral viral load of those infected with the new coronavirus and was not able to establish a significant reduction in the viral load in saliva after 30 minutes of follow-up in 10 patients (Gottsauner et al. 2020).

\section{Assessment of risk of bias}

After using the ROBINS-I tool we concluded that the four studies analyzed have a critical (Gottsauner et al. 2020; Martínez Lamas et al. 2020; Yoon et al. 2020) or serious risk (Seneviratne et al. 2020) of bias mainly due to not controlling for confounding factors and the selection of patients. Regarding the first domain, the majority of studies did not take into account the beginning of COVID-19 symptoms, did not control the ingestion of food or water by patients prior to the start of the intervention, and in one study participants had been taking antiviral medication during the duration of the study (Yoon et al. 2020). For the second domain, these studies had very small samples, with the largest including only 16 patients (Seneviratne et al. 2020). Moreover, the characteristics of the participants were very heterogeneous between the studies and, furthermore, the studies did not clearly establish inclusion or exclusion criteria.

\section{DISCUSSION}

The main objective of this living systematic review was to evaluate the effect of different kinds of mouthrinses on the viral load of SARS-CoV-2 in the saliva of patients with COVID-19. Four studies were included; two published in original article format and two as short communications. They included patients with positive SARS-CoV-2 infection confirmed by RT-PCR (32 participants in total), who underwent oral rinses with $\mathrm{H} 2 \mathrm{O} 2$ at $1 \%, \mathrm{PI}$ at $0.5 \%$ or $1 \%, \mathrm{CHX}$ at $0.2 \%$ or $0.12 \%$ or $\mathrm{CPC}$ at $0.075 \%$. Only one of the studies included a control group in which sterile water was used. All studies included a baseline assessment of viral load in saliva or oropharyngeal secretions and between two and five follow-up periods with a minimum of five minutes and a maximum of six hours after the intervention. Measurement of viral load was reported in copies $/ \mathrm{mL}$ and one of the studies used the cycle threshold value to determine a detectable viral load. Three of the studies identified a significant reduction in viral load up to 3,4 , and 6 hours after the use of mouth-rinses with $\mathrm{PI}, \mathrm{CHX}$, and CPC or PI vs. sterile water, respectively, while one study did not identify a significant reduction in viral load after the use of $\mathrm{H} 2 \mathrm{O} 2$ rinses. Likewise, the four studies evaluated were at high risk of bias.

The results of three studies reported that the use of mouth-rinses with $\mathrm{PI}, \mathrm{CHX}$, or CPC could reduce the viral load of SARS-CoV-2 in the saliva of confirmed COVID-19 patients. However, it should be taken into account that the evidence to date corresponds to studies with a small sample size (between 2 and 16 
medRxiv preprint doi: https://doi.org/10.1101/2021.03.23.21254214; this version posted March 26, 2021. The copyright holder for this preprint (which was not certified by peer review) is the author/funder, who has granted medRxiv a license to display the preprint in perpetuity.

It is made available under a CC-BY 4.0 International license .

patients), with a risk of serious or critical bias, mainly due to the impossibility of controlling the potential effect of confounding variables. For example, the studies did not take into account variables such as the onset of COVID-19 symptoms or the consumption of food prior to the intervention, which could have an impact on the viral load in saliva. Therefore, with the results of these studies, it is not possible to conclude that the reduction in viral load is due solely to the effect of mouth-rinses. In addition, despite three of the four studies included showing a positive effect on reducing the viral load of SARS-CoV-2, we could not say that these results are consistent, due to the marked heterogeneity among the studies. These differences were mainly identified in the measurement units used to express viral load, the number and periods of follow-up, the concentrations of antiseptic substances, and the procedures for the use of mouth-rinses, among other aspects.

On the other hand, most of the studies analyzed suggest that different types of mouth-rinses reduce the viral load of SARS-CoV-2 in the saliva of infected patients up to six hours after their application. This could translate into a reduction in the viral content found in aerosols generated during dental procedures, resulting in a reduction in the spread of the disease in health personnel and patients without infection. However, post-intervention measurements in the studies included were not performed after the performance of a dental procedure. This is important because it is hypothesized that SARS-CoV-2 would be present in the salivary glands of infected patients (Xu, J. et al. 2020; Xu, R. et al. 2020), being expelled into the oral cavity through saliva (Sakanashi et al. 2021; Wyllie et al. 2020; Zhu et al. 2020). So, given that salivary secretion is stimulated during oral instrumentation for dental procedures, it would, therefore, be reasonable to conclude that the duration in the reduction of viral load would probably be of shorter in clinical scenarios. Evidence from studies of a higher methodological level, conducted in real or simulated clinical settings are of vital importance to better understand the effect of mouth-rinses on SARS-CoV-2 viral load in the saliva of patients with COVID-19.

One of the limitations of the study is that due to the low quality of the studies, small sample size, as well as the heterogeneity reported in terms of follow-up periods, and reporting of viral load measurement, the calculation of a meta-analysis would have very limited utility. However, an extensive bibliographic search has been carried out in seven databases, and the search has also been extended to preprint repositories including medRxiv, and bioRxiv, in order to cover the greatest amount of evidence available on the subject. Likewise, the present study has a living systematic review design in order to perform future updates of this study according to the results of completed or ongoing clinical trials registered in the ClinicalTrials.gov portal. This will enable the adoption of a more conclusive position for or against the use of mouth-rinses in reducing the viral load of SARS-CoV-2 in the saliva of patients with COVID-19.

In conclusion, according to the present systematic review, the effect of the use of mouth-rinses on the viral load of SARS-CoV-2 continues to be uncertain. The emission of recommendations by governmental organizations around the world about the use of these mouth-rinses as a preventive measure towards infection by SARS-CoV-2 could generate a false sensation of security among dentists, care staff, and patients, which could subsequently lead to a groundless reduction in the use of known effective measures for the prevention of infection and dissemination of COVID-19 during aerosol-generating procedures resulting in an increment in contagion rates.

Acknowledgments: The authors are grateful to Donna Pringle for reviewing the language and style. 
medRxiv preprint doi: https://doi.org/10.1101/2021.03.23.21254214; this version posted March 26, 2021. The copyright holder for this preprint (which was not certified by peer review) is the author/funder, who has granted medRxiv a license to display the preprint in perpetuity.

It is made available under a CC-BY 4.0 International license .

\section{References}

Alzahrani M. 2021. The efficacy of pre-procedural mouth rinses on SARS-CoV-2 saliva viral load: A randomized control clinical trial. clinicaltrials.gov.

American Dental Association. 2020. ADA interim guidance for minimizing risk of COVID-19 transmission. . 8 p. .

Bramer WM, Giustini D, de Jonge GB, Holland L, Bekhuis T. 2016. De-duplication of database search results for systematic reviews in EndNote. Journal of the Medical Library Association: JMLA. 104(3):240-3.

Interim Infection Prevention and Control Recommendations for Healthcare Personnel During the Coronavirus Disease 2019 (COVID-19) Pandemic [Internet]; c2020 [cited 2021 Mar 23,].

Available from: https://www.cdc.gov/coronavirus/2019-ncov/hcp/infection-controlrecommendations.html .

Dong E, Du H, Gardner L. 2020. An interactive web-based dashboard to track COVID-19 in real time. The Lancet Infectious Diseases. 20(5):533-4.

Elliott JH, Synnot A, Turner T, Simmonds M, Akl EA, McDonald S, Salanti G, Meerpohl J, MacLehose H, Hilton J, et al. 2017. Living systematic review: 1. introduction-the why, what, when, and how. J Clin Epidemiol. 91:23-30.

Ghazy RM, Almaghraby A, Shaaban R, Kamal A, Beshir H, Moursi A, Ramadan A, Taha SHN. 2020. A systematic review and meta-analysis on chloroquine and hydroxychloroquine as monotherapy or combined with azithromycin in COVID-19 treatment. Scientific Reports. 10(1):22139.

Gottsauner MJ, Michaelides I, Schmidt B, Scholz KJ, Buchalla W, Widbiller M, Hitzenbichler F, Ettl T, Reichert TE, Bohr C, et al. 2020. A prospective clinical pilot study on the effects of a hydrogen peroxide mouthrinse on the intraoral viral load of SARS-CoV-2. Clin Oral Investig. 24(10):3707-13.

Jacox L. 2021. Mouth rinses for inactivation of COVID SARS-2 virus. clinicaltrials.gov.

Kpozehouen EB, Chen X, Zhu M, Macintyre CR. 2020. Using open-source intelligence to detect early signals of COVID-19 in china: Descriptive study. JMIR Public Health and Surveillance. 6(3):e18939.

Martínez Lamas L, Diz Dios P, Pérez Rodríguez MT, Del Campo Pérez V, Cabrera Alvargonzalez JJ, López Domínguez AM, Fernandez Feijoo J, Diniz Freitas M, Limeres Posse J. 2020. Is povidone iodine mouthwash effective against SARS-CoV-2? first in vivo tests. Oral Dis. :odi.13526.

Meister TL, Brüggemann Y, Todt D, Conzelmann C, Müller JA, Groß R, Münch J, Krawczyk A, Steinmann Jö, Steinmann J, et al. 2020. Virucidal efficacy of different oral rinses against severe acute respiratory syndrome coronavirus 2 . J Infect Dis. 222(8):1289-92. 
medRxiv preprint doi: https://doi.org/10.1101/2021.03.23.21254214; this version posted March 26, 2021. The copyright holder for this preprint (which was not certified by peer review) is the author/funder, who has granted medRxiv a license to display the preprint in perpetuity.

It is made available under a CC-BY 4.0 International license .

Moher D. 2009. Preferred reporting items for systematic reviews and meta-analyses: The PRISMA statement. Ann Intern Med. 151(4):264.

Moher D, Shamseer L, Clarke M, Ghersi D, Liberati A, Petticrew M, Shekelle P, Stewart LA, PRISMA-P Group. 2015. Preferred reporting items for systematic review and meta-analysis protocols (PRISMA-P) 2015 statement. Systematic Reviews. 4:1.

O'Donnell VB, Thomas D, Stanton R, Maillard J, Murphy RC, Jones SA, Humphreys I, Wakelam MJO, Fegan C, Wise MP, et al. 2020. Potential role of oral rinses targeting the viral lipid envelope in SARS-CoV-2 infection. Function (Oxford, England). 1(1):zqaa002.

Ouzzani M, Hammady H, Fedorowicz Z, Elmagarmid A. 2016. Rayyan-a web and mobile app for systematic reviews. Systematic Reviews. 5(1):210.

Peng X, Xu X, Li Y, Cheng L, Zhou X, Ren B. 2020. Transmission routes of 2019-nCoV and controls in dental practice. International Journal of Oral Science. 12(1):9.

Reis INR, do Amaral, Guilherme Castro,Lima Silva, Mendoza AAH, das Graças YT, MendesCorrea M, Romito GA, Pannuti CM. 2021. Can preprocedural mouthrinses reduce SARSCoV-2 load in dental aerosols? Med Hypotheses. 146:110436.

Sakanashi D, Asai N, Nakamura A, Miyazaki N, Kawamoto Y, Ohno T, Yamada A, Koita I, Suematsu $\mathrm{H}$, Hagihara M, et al. 2021. Comparative evaluation of nasopharyngeal swab and saliva specimens for the molecular detection of SARS-CoV-2 RNA in japanese patients with COVID-19. Journal of Infection and Chemotherapy: Official Journal of the Japan Society of Chemotherapy. 27(1):126-9.

Seneviratne CJ, Balan P, Ko KKK, Udawatte NS, Lai D, Ng DHL, Venkatachalam I, Lim KS, Ling ML, Oon L, et al. 2020. Efficacy of commercial mouth-rinses on SARS-CoV-2 viral load in saliva: Randomized control trial in singapore. Infection. .

Villar OM. 2021. Double-blind, randomized, parallel, placebo-controlled clinical study to evaluate the viral load of SARS-CoV-2 in the oral cavity of SARS-CoV-2 positive subjects after the use of a mouthwash containing cetylpyridinium chloride $0,07 \%$. clinicaltrials.gov.

Coronavirus disease (COVID-19) advice for the public [Internet]; c2021 [cited 2021 23-03-]. Available from: https://www.who.int/emergencies/diseases/novel-coronavirus-2019/advicefor-public files/490/advice-for-public.html .

Wyllie AL, Fournier J, Casanovas-Massana A, Campbell M, Tokuyama M, Vijayakumar P, Warren JL, Geng B, Muenker MC, Moore AJ, et al. 2020. Saliva or nasopharyngeal swab specimens for detection of SARS-CoV-2. N Engl J Med. 383(13):1283-6.

Xu J, Li Y, Gan F, Du Y, Yao Y. 2020. Salivary glands: Potential reservoirs for COVID-19 asymptomatic infection. J Dent Res. 99(8):989.

Xu R, Cui B, Duan X, Zhang P, Zhou X, Yuan Q. 2020. Saliva: Potential diagnostic value and transmission of 2019-nCoV. International Journal of Oral Science. 12(1):11. 
medRxiv preprint doi: https://doi.org/10.1101/2021.03.23.21254214; this version posted March 26, 2021. The copyright holder for this preprint (which was not certified by peer review) is the author/funder, who has granted medRxiv a license to display the preprint in perpetuity.

It is made available under a CC-BY 4.0 International license.

Yoon JG, Yoon J, Song JY, Yoon SY, Lim CS, Seong H, Noh JY, Cheong HJ, Kim WJ. 2020. Clinical significance of a high SARS-CoV-2 viral load in the saliva. J Korean Med Sci. 35(20):e195.

Zhu J, Guo J, Xu Y, Chen X. 2020. Viral dynamics of SARS-CoV-2 in saliva from infected patients. J Infect. 81(3):e48-50. 
medRxiv preprint doi: https://doi.org/10.1101/2021.03.23.21254214; this version posted March 26, 2021. The copyright holder for this preprint (which was not certified by peer review) is the author/funder, who has granted medRxiv a license to display the preprint in perpetuity.

It is made available under a CC-BY 4.0 International license .

Figure 1. Flow chart of study selection according to the PRISMA statement.

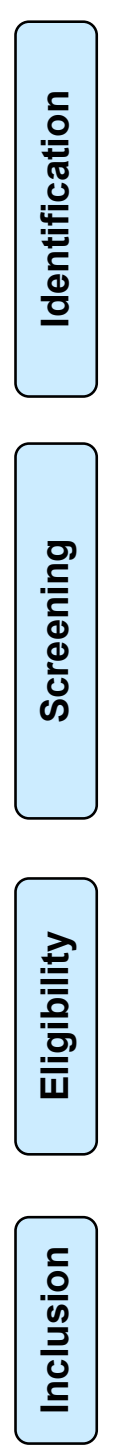

\section{Records identified through database search $(n=595)$}

Records after removing duplicates

$$
(n=381)
$$
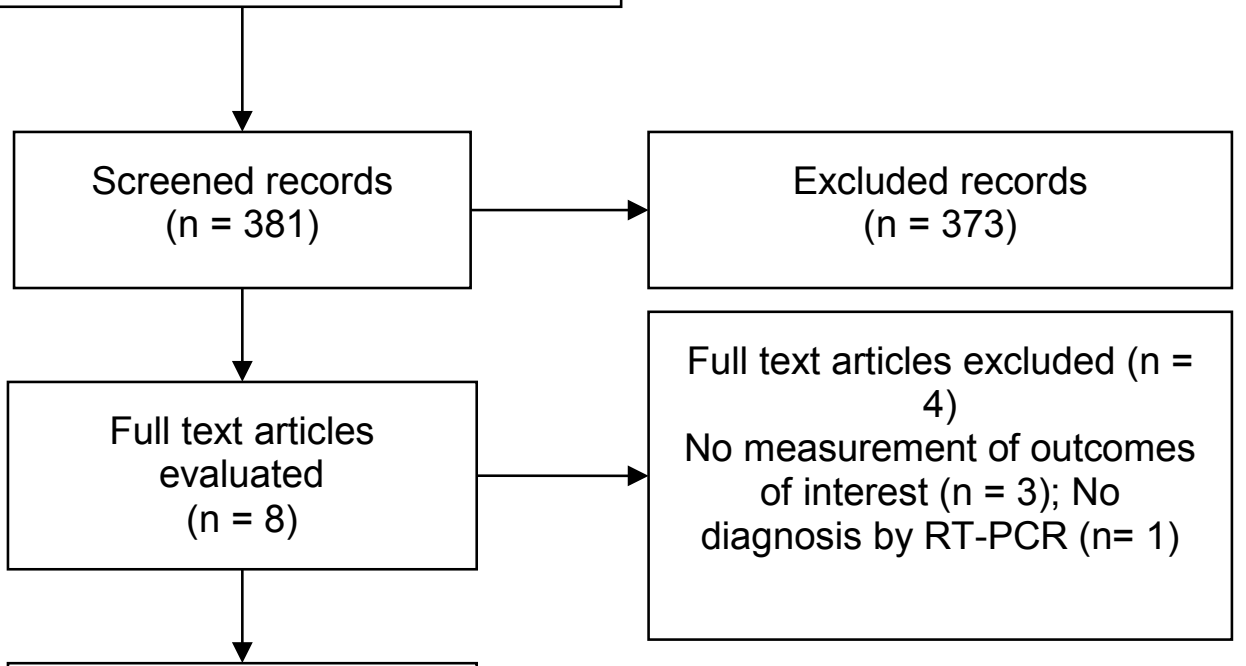

Studies included in the qualitative synthesis

$$
(n=4)
$$


medRxiv preprint doi: https://doi.org/10.1101/2021.03.23.21254214; this version posted March 26, 2021. The copyright holder for this preprint (which was not certified by peer review) is the author/funder, who has granted medRxiv a license to display the preprint in perpetuity.

It is made available under a CC-BY 4.0 International license.

Figure 2. Risk of bias using ROBINS-I.

Risk of bias domains

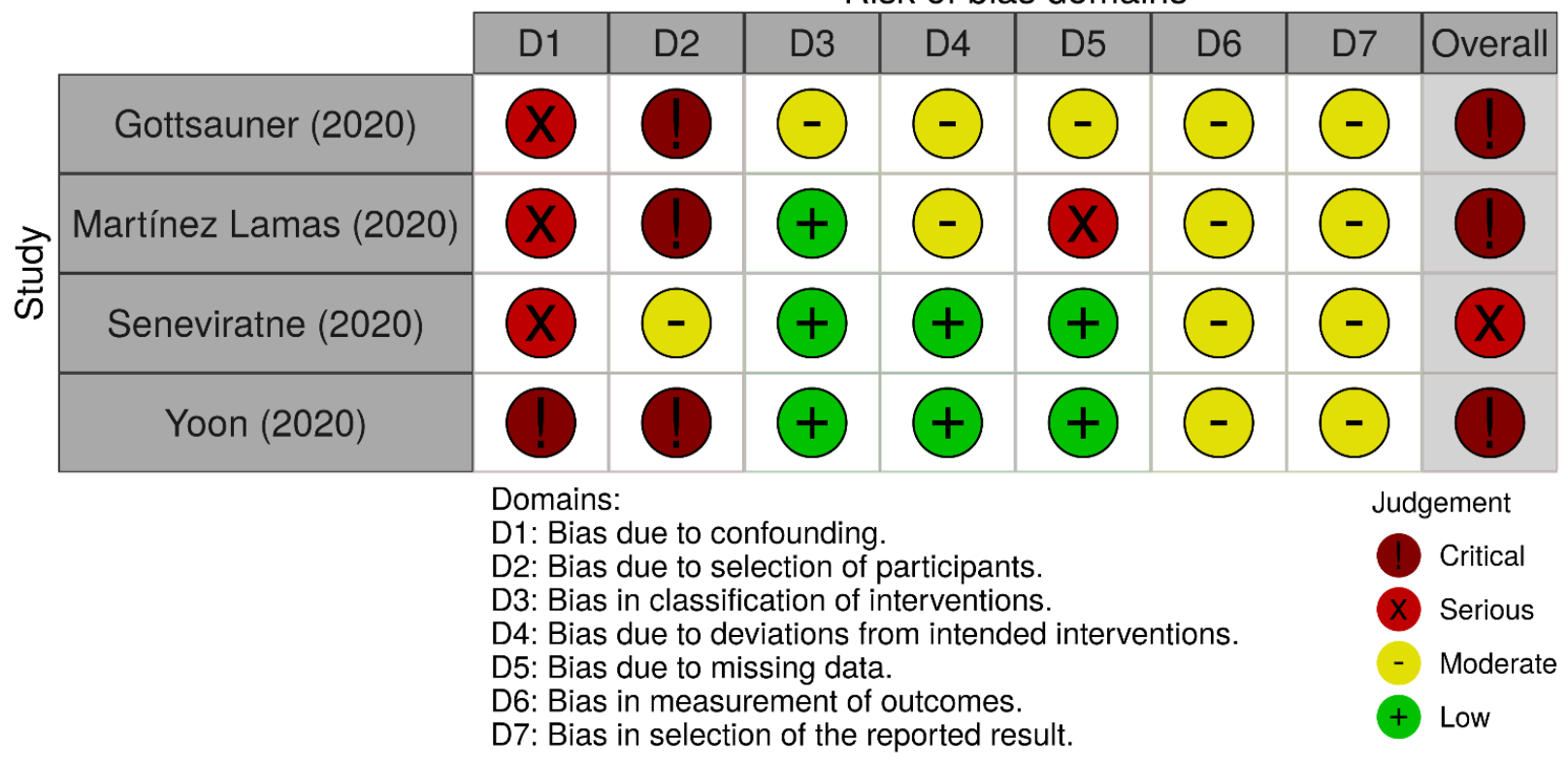


Table 1. Characteristics of the studies included.

\begin{tabular}{|c|c|c|c|c|c|c|c|c|c|}
\hline Author/Year & $\begin{array}{c}\text { Type of } \\
\text { publication }\end{array}$ & Country & Setting & $\begin{array}{c}\text { Sample } \\
\text { (n) }\end{array}$ & $\begin{array}{l}\text { COVID-19 } \\
\text { Diagnosis }\end{array}$ & $\begin{array}{c}\text { Mouth-rinse } \\
\text { type }\end{array}$ & Experiment details & $\begin{array}{l}\text { Primary } \\
\text { Outcome } \\
\text { evaluated }\end{array}$ & $\begin{array}{l}\text { Follow- } \\
\text { up (time) }\end{array}$ \\
\hline $\begin{array}{l}\text { Gottsauner } \\
(2020)\end{array}$ & $\begin{array}{l}\text { Short } \\
\text { communication }\end{array}$ & Germany & Hospital & 10 & $\begin{array}{l}\text { Only patients with } \\
\text { a positive RT- } \\
\text { PCR test for } \\
\text { SARS-CoV-2 } \\
\text { within the last } 72 \\
\text { h were included in } \\
\text { this study }\end{array}$ & $20 \mathrm{~mL} \mathrm{1 \%} \mathrm{H} 2 \mathrm{O} 2$ & $\begin{array}{l}\text { Patients were asked to gargle their } \\
\text { mouth and throat with } 20 \mathrm{~mL} 0.9 \% \\
\text { NaCl for } 30 \mathrm{~s} \text { in order to acquire a } \\
\text { baseline oropharyngeal specimen } \\
\text { for the SARS-CoV- } 2 \text { real-time RT- } \\
\text { PCR test. Immediately afterwards, } \\
\text { patients had to perform a mouth } \\
\text { rinse with } 20 \mathrm{~mL} 1 \% \mathrm{H} 2 \mathrm{O} 2 \text { by } \\
\text { gargling their mouth and throat for } \\
30 \mathrm{~s} \text {. Thirty minutes after this mouth } \\
\text { rinse, an-other oropharyngeal } \\
\text { specimen for the SARS-CoV- } 2 \mathrm{RT}- \\
\text { PCR test was acquired by letting the } \\
\text { patients gargle their mouth and } \\
\text { throat with } 20 \text { mL } 0.9 \% \text { NaCl for } 30 \\
\mathrm{~s} \text {. The respective quantities of } \\
\text { copies/mL of SARS-CoV-2 RNA } \\
\text { were analyzed by RT-PCR. }\end{array}$ & $\begin{array}{l}\text { Intraoral viral } \\
\text { load in } \\
\text { SARS-CoV- } \\
\text { 2-positive } \\
\text { patients }\end{array}$ & $\begin{array}{l}30 \\
\text { minutes }\end{array}$ \\
\hline $\begin{array}{l}\text { Martínez } \\
\text { Lamas } \\
(2020)\end{array}$ & $\begin{array}{l}\text { Short } \\
\text { communication }\end{array}$ & Spain & Hospital & 4 & RT-PCR assay & $15 \mathrm{ml}$ of $1 \% \mathrm{PI}$ & $\begin{array}{l}\text { Patients were asked to cough out } \\
\text { saliva from their throat into a sterile } \\
\text { container, and } 2 \mathrm{~mL} \text { of viral } \\
\text { transport medium was added at } \\
\text { baseline after which each } \\
\text { participant rinsed their mouth with } \\
15 \mathrm{ml} \text { of } 1 \% \text { PI for } 1 \text { min. Afterwards } \\
\text { saliva samples were collected at } 5 \\
\text { min, } 1 \mathrm{~h}, 2 \mathrm{~h} \text { and } 3 \text { hours. }\end{array}$ & $\begin{array}{l}\text { Salivary viral } \\
\text { load of } \\
\text { SARS-CoV- } \\
2 \text { in } 4 \\
\text { patients with } \\
\text { COVID-19 }\end{array}$ & 3 hours \\
\hline $\begin{array}{l}\text { Seneviratne } \\
(2020)\end{array}$ & Original article & Singapore & Hospital & 16 & $\begin{array}{l}\text { Positive nasal } \\
\text { swabs for SARS- } \\
\text { CoV-2 based on } \\
\text { RT-PCR assay }\end{array}$ & 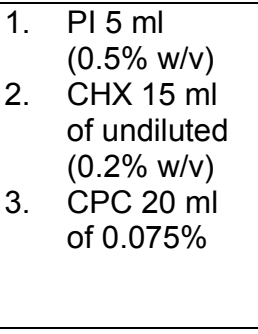 & $\begin{array}{l}\text { Three } \mathrm{mL} \text { of saliva was collected by } \\
\text { passive drool technique from all the } \\
\text { enrolled COVID-19 patients at } \\
\text { baseline and after rinsing their } \\
\text { mouth with the corresponding } \\
\text { mouthwash (PI, CHX, CPC or } \\
\text { water). Three additional samples } \\
\text { were obtained at } 5 \text { min, } 3 \text { hours and } \\
6 \text { hours. }\end{array}$ & $\begin{array}{l}\text { Salivary } \\
\text { SARS-CoV- } \\
2 \text { viral load }\end{array}$ & 6 hours \\
\hline Yoon (2020) & Original article & Korea & Hospital & 2 & $\begin{array}{l}\text { Real-time RT- } \\
\text { PCR }\end{array}$ & $\begin{array}{l}\mathrm{CHX}(0.12 \%, 15 \\
\mathrm{mL}) \text { for } 30 \\
\text { seconds }\end{array}$ & $\begin{array}{l}\text { During hospital days } 3 \text { and } 6 \text {, } \\
\text { patients were asked to collect saliva } \\
\text { samples while being supervised by }\end{array}$ & $\begin{array}{l}\text { Viral } \\
\text { dynamics in } \\
\text { various body }\end{array}$ & 4 hours \\
\hline
\end{tabular}




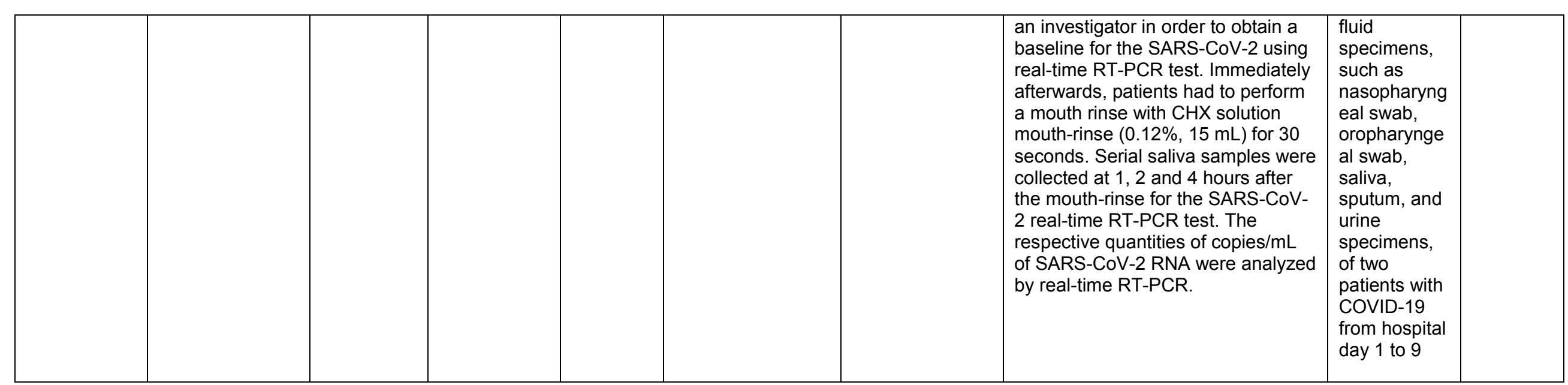

RT-PCR: reverse-transcription polymerase chain reaction.

$\mathrm{H} 2 \mathrm{O} 2$ : hydrogen peroxide; PI: povidone-iodine; $\mathrm{CHX}$ : chlorhexidine gluconate; $\mathrm{CPC}$ : cetylpyridinium chloride; NaCl: Sodium Chloride. 
Table 2. Summary of results of the studies.

\begin{tabular}{|c|c|c|c|c|}
\hline Author/Year & Sample (n) & Intervention & Comparator & \begin{tabular}{|c|} 
Results for primary outcome (viral load) \\
\end{tabular} \\
\hline $\begin{array}{l}\text { Gottsauner } \\
(2020)\end{array}$ & 10 & $20 \mathrm{~mL} 1 \% \mathrm{CHX}$ & None & $\begin{array}{l}\text { Baseline: Median } 1.8 \times 10^{3}\left(\text { IQR } 3,1 \times 10^{2} \text { and } 4.7 \times 10^{4}\right) \\
\text { copies/mL of SARS-CoV-2 RNA } \\
30 \text { min: Median } 1.5 \times 10^{3}\left(\text { IQR } 8.3 \times 10^{2} \text { and } 3.4 \times 10^{4}\right) \\
\text { copies/mL of SARS-CoV-2 RNA }\end{array}$ \\
\hline $\begin{array}{l}\text { Martínez } \\
\text { Lamas (2020) }\end{array}$ & 4 & $15 \mathrm{ml}$ of $1 \% \mathrm{PI}$ & None & $\begin{array}{ll}- & \text { Baseline: } \operatorname{loan} 3.75 \log 10 \mathrm{copies} / \mathrm{mL} \\
\text { - } & \text { 5min: mean } 3.9 \log 10 \mathrm{copies} / \mathrm{mL} \\
\text { - } & \text { 2h: mean } 2.72 \log 10 \mathrm{copies} / \mathrm{mL} \\
\text { - } & \text { 3h: mean } 2.27 \log 10 \mathrm{copies} / \mathrm{mL} \\
\end{array}$ \\
\hline $\begin{array}{l}\text { Seneviratne } \\
(2020)\end{array}$ & $\begin{array}{l}\text { PI group }(n=4) \\
\text { CHX group }(n=6) \\
\text { CPC group }(n=4) \\
\text { water as control } \\
\text { group }(n=2)\end{array}$ & $\begin{array}{ll}\text { 1. } & \text { PI } 5 \mathrm{ml}(0.5 \% \mathrm{w} / \mathrm{v}) \\
\text { 2. } & \mathrm{CHX} 15 \mathrm{ml} \text { of } \\
& \text { undiluted }(0.2 \% \mathrm{w} / \mathrm{v}) \\
\text { 3. } & \text { CPC } 20 \mathrm{ml} \text { of } \\
& 0.075 \%\end{array}$ & Sterile water & $\begin{array}{l}\text { Baseline: } \\
\text { Cycle Threshold value PI group } 22 \\
\text { CHX group } 30 \\
\text { CPC group } 33 \\
\text { water group } 26 \\
\quad 5 \text { min: Cycle Threshold value } \\
\text { PI group } 24 \\
\text { CHX group } 28 \\
\text { CPC group } 34 \\
\text { water group } 25 \text {--- CPC vs. water } p<0.05 \\
\text { PI group } 24 \\
\text { CHX group } 30 \\
\text { CPC group } 31 \\
\text { water group } 24 \\
\quad 6 \text { h: Cycle Threshold value } \\
\text { PI group } 22 \\
\text { CHX group } 28 \\
\text { CPC group } 32 \\
\text { water group } 23 \text {--- CPC vs. water } p<0.05, \text { PI vs water } p<0.01\end{array}$ \\
\hline Yoon (2020) & 2 & $\begin{array}{l}\text { CHX solution } \\
\text { mouthwash }(0.12 \%, 15 \\
\mathrm{mL}) \text { for } 30 \text { seconds }\end{array}$ & None & $\begin{array}{l}\text { Hospital Day 3: } \\
\text { - } \quad \text { Baseline: mean } 5.865 \log 10 \mathrm{copies} / \mathrm{mL} \\
\text { - } 1 \mathrm{~h}: \text { non detectable } \\
\text { - } \quad 4 \mathrm{~h} \text { : non detectable } \\
\text { Hospital Day } 6.39 \log 10 \mathrm{copies} / \mathrm{mL} \\
\text { - } \quad \text { aaseline: mean } 4.68 \log 10 \mathrm{copies} / \mathrm{mL} \\
\text { - } 1 \mathrm{~h}: \text { mean } 4.315 \log 10 \mathrm{copies} / \mathrm{mL} \\
-\quad 2 \mathrm{~h}: \text { mean } 3.39 \log 10 \mathrm{copies} / \mathrm{mL} \\
-\quad 4 \mathrm{~h}: \text { mean } 4.495 \log 10 \mathrm{copies} / \mathrm{mL}\end{array}$ \\
\hline
\end{tabular}

IQR: interquartile range; PI: povidone-iodine; $\mathrm{CHX}$ : chlorhexidine gluconate; CPC: cetylpyridinium chloride. 